\title{
Letter to the Editor: Pyruvate Carboxylase Activity in Amniotic Fluid Cells
}

\author{
T. L. HANSEN AND E. CHRISTENSEN \\ Section of Clinical Genetics, Department of Pediatrics, Rigshospitalet, University of Copenhagen, Blegdamsvej 9 , \\ DK-2100 Copenhagen, Denmark
}

\begin{abstract}
In a recent letter (1), Feldman and Wolf report about puruvate carboxylase activity in cultured amniotic fluid cells and stated that "to our knowledge, there has been no documentation of measureable activity in this tissue source."

However, we have reported on pyruvate carboxylase activity as well in cultured fibroblasts as in cultured amniotic fluid cells in 1977 (4) and 1978 (2). A more detailed report has appeared in 1979 (3). The pyruvate carboxylase activity reported by Feldman and Wolf $(1)$ is similar to ours.

In cultured amniotic fluid cells, we found an activity of $0.66 \pm$ $0.17 \mathrm{nmoles} / \mathrm{mg}$ protein $/ \mathrm{min}(n=5)$, which is comparable with the activity in cultured fibroblasts. Furthermore, we stated that, "these results indicate that prenatal diagnosis of pyruvate carboxylase deficiency may be possible" $(2-4)$.
\end{abstract}

Copyright (c) 1980 International Pediatric Research Foundation, Inc. $0031-3998 / 80 / 1412-1412 \$ 02.00 / 0$
Whether prenatal diagnosis is possible has to await a pregnancy at risk for this disorder, where a low activity of pyruvate carboxylase activity can be confirmed in the liver from the fetus.

\section{REFERENCES AND NOTES}

1. Feldman, G. L., and Wolf, B.: Letter to the Editor: Measurement of Pyruvate Carboxylase Activity in Amniotic Fluid Cells. Pediatr. Res., 14: 153 (1979).

2. Hansen, T. L., and Christensen, E.: Studies on pyruvate carboxylase from human diploid fibroblasts and amniotic fluid cells. The Society for the Study of Inborn Errors of Metabolism, 16. Annual Meeting, Bristol, England (1978).

3. Hansen, T. L., and Christensen, E.: Studies on pyruvate carboxylase from cultured fibroblasts and amniotic fluid cells. J. Inher. Metab. Dis., 2: 23 (1979).

4. Hansen, T. L., Christensen, E. and Brandt, N. J.: Pyruvate carboxylase activity in cultured human fibroblasts and amniotic fluid cells. Abstract A 1-8 052, 1 th FEBS Meeting, Copenhagen, August (1977). 